Article

\title{
Conceptualizing the Parliamentarization and Politicization of European Policies
}

\author{
Niels Gheyle \\ Department of Political Sciences, Ghent University, 9000 Ghent, Belgium; E-Mail: niels.gheyle@ugent.be
}

Submitted: 30 March 2019 | Accepted: 14 June 2019 | Published: 27 September 2019

\begin{abstract}
In the past 20 years, two related literature strands have gradually moved centre stage of the attention of EU Studies scholars. The first is preoccupied with the 'politicization of European integration', a multi-faceted concept that aims to tie together a multitude of political and societal manifestations underlying an increasing controversiality of the EU. A second concerns the parliamentarization of the EU, referring to the changing (institutional) role and EU-related activities national parliaments engage in. The key point of this contribution is simple, but often overlooked: We can and should be seeing parliamentarization as a necessary, yet insufficient, component of a wider process of politicization. Doing so goes beyond the often ad hoc or pars pro toto theoretical assumptions in both literature strands, sheds new light on the normative consequences attached to these phenomena, and furthers a more complete understanding of how a 'comprehensive' politicization of European policies develops.
\end{abstract}

\section{Keywords}

communication; Europeanization; parliamentary; parliamentarization; politicization; national parliaments

\section{Issue}

This article is part of the issue "Out of the Shadows, Into the Limelight: Parliaments and Politicisation", edited by Christine Neuhold (Maastricht University, The Netherlands) and Guri Rosén (University of Oslo, Norway).

(C) 2019 by the author; licensee Cogitatio (Lisbon, Portugal). This article is licensed under a Creative Commons Attribution 4.0 International License (CC BY).

\section{Introduction}

It is by now long overdue to state that the EU no longer flies under the political and societal radar. What was once characterized by a stance of indifference (or a 'permissive consensus') by the wider public, has slowly but steadily turned into an expansion of the scope of conflict surrounding the EU (De Wilde, 2011a; Hooghe \& Marks, 2009). This change has its origins somewhere around the mid-1990s and has become a focal point of scholarly attention since the failure of the Constitutional Treaty in 2004. 'Politicization' was argued to have kicked in, referring to a state of political and societal debate characterized by features such as an increasingly polarized public, frequent media visibility, electoral positioning, and Euro protests. All of this directed towards the EU itself or particularly salient policies, which together was seen as an "awakening of the sleeping giant" (Van der Eijk \& Franklin, 2004). Since then, politicization scholars have set out the task of conceptualizing this complex phenomenon, constructing analytical frameworks to study its forms and appearances, explain its origins and dynamics, and evaluate the (normative) consequences (for conceptual overviews see De Wilde, Leupold, \& Schmidtke, 2016; Gheyle, 2019).

During the same time period, a different but related literature strand focused on the role and EU-related activities of national parliaments in the EU multilevel system. The emphasis here is on how national parliaments adapt, institutionally, to take pressures of European integration into account, but also on the question of whether and how they are actively engaging with EU policy-making. The latter occurs by scrutinizing their governments, or communicating European policies much more frequently-here labelled as 'behavioural' parliamentarization (Auel, 2015; Goetz \& Meyer-Sahling, 2008). All of this despite or because of the fact that they had initially been labelled the 'losers of European integration', to the benefit of execu- 
tives and/or the European Parliament (Maurer \& Wessels, 2001). The further strengthened formal role of national parliaments through the Lisbon Treaty (Neuhold \& Smith, 2016) and the visible part some parliaments have played in recently salient episodes, such as the CETA-saga (Bollen, 2018), have only fuelled the attention.

This contribution takes issue with the relationship between these two developments-(behavioural) parliamentarization and politicization-from a conceptual and analytical point of view. The key point is simple, but arguably often overlooked: We can and should be seeing (behavioural) parliamentarization as a necessary, yet insufficient, component of the politicization of European integration or specific policies, and not as separate, independent, processes that react to each other. In other words, (behavioural) parliamentarization is not equal to politicization, but a 'comprehensive' understanding of politicization cannot exist without it.

We 'can' make this link, first of all, because the conceptual and analytical contributions in both literature strands show very clear overlaps, which often go unrecognized when looking from one point of view. Crucially, we also 'should' re-conceptualize the relationship as follows, as this: (i) goes beyond ad hoc or pars pro toto theoretical assumptions that are sometimes used in these literature strands; (ii) sheds new light on the normative consequences usually attached to them; and (iii) furthers a research agenda focused on a more complete understanding of how 'comprehensive' politicization of European policies develops. In sum, this discussion is more than a semantic exercise, as it benefits the scholarly discussion of which role parliaments play in salient policies, while at the same time adding to our understanding of the complex politicization concept-both key aims of this special issue.

Beyond these specific conceptual considerations, this contribution has two more overarching goals. The first is to trigger more fine-grained conceptual and analytical reflection about two concepts that are-due to their popularity and importance-sometimes readily used without thorough conceptual consideration. Doing so runs the risk of applying the same broad labels to varying empirical phenomena, hence undermining our collective knowledge. Secondly, it aims to serve as a modest research agenda for studying behavioural parliamentarization as connected to wider politicization dynamics. In doing so, it sets the scene for several empirically grounded contributions in this special issue.

The article is structured as follows: Section 2 turns to the literature on the role and EU-related activities of national parliaments. Section 3 focuses on the 'politicization' phenomenon, unpacking its multi-faceted nature, manifestations, and settings. Section 4 then makes the 'so what?' of this contribution explicit: Why does it matter that we see (behavioural) parliamentarization as a necessary, but insufficient, component of politicization? Section 5 ends with some concluding remarks and shortcomings that can be taken up by further research.

\section{Parliamentarization of the EU}

To make sense of the relationship between European integration and domestic political systems, the concept of 'Europeanization' is commonly invoked, referring to "an incremental process re-orienting the direction and shape of politics to the degree that [EU] political and economic dynamics become part of the organisational logic of national politics and policy-making" (Ladrech, 1994, p. 69). When the object of Europeanization is the national parliamentary system, some authors speak of the degree of 'parliamentarization' of the EU. Herranz-Surrallés (2018), for example, defines parliamentarization as the "greater involvement of parliaments in scrutinizing and shaping regional and global governance" (p. 31). This is a broad interpretation, and as such, a 'greater involvement' can point both to the institutional ability to be involved in the shaping and scrutinizing of governance (e.g., RoedererRynning \& Schimmelfennig, 2012), or to the actual practice of shaping policy, in terms of scrutiny, coordination, or communication (e.g., Rozenberg \& Hefftler, 2016). These 'institutional' responses, on the one hand, and the 'attitudinal' and 'behavioural' responses, on the other hand, are recognized categories of the Europeanization of national parliaments (Goetz \& Meyer-Sahling, 2008).

Early contributions came to the conclusion of a deparliamentarization of the EU: (the appearance of) a decreasing and eroding role for national parliaments, increasingly unable to shape European governance (Raunio, 2009). The argument went that national parliaments were either uninterested in engaging with EU issues (Auel \& Raunio, 2014b), or not able to do so effectively. Given that EU competences were simultaneously growing, this would result in them being the 'losers of integration' (Maurer \& Wessels, 2001).

Nevertheless, several scholars documented how national parliaments actively started to 'fight back' by adapting institutionally to deal with this challenge of European integration (Raunio \& Hix, 2000). They did so, for example, by establishing specific European Affairs Committees (EACs), increasing their informational rights with respect to EU or national executives, or establishing inter-parliamentary fora to be in a better position to scrutinize their governments (Raunio, 2009). A consensus emerged on the basic point that "national institutions have made substantial efforts in order to cope with the requirements of the Union" (Wessels, Maurer, \& Mittag, 2003, p. 414). Raunio (2009) backs this up by concluding in a review article that national parliaments are now generally in a much stronger position to scrutinize their governments than they were in the 1990s. Several provisions in the Lisbon Treaty with respect to national parliaments (such as the establishment of an 'Early Warning System') have further strengthened this development of 'institutional parliamentarization' (Neuhold \& Smith, 2016).

The more pressing question, then, is whether national parliaments actually make use of these provi- 
sions to assert themselves in the EU multi-level system. Indeed, as Auel (2015) argues, institutional opportunities remain latent until they are utilized. Hence, to fully make sense of the parliamentarization of the EU, analyses of: (i) attitudes and role conceptions of members of parliament (MPs); and (ii) their EU-related behaviour and activities over time, are necessary. First, changes in attitudes and role conceptions of MPs can result in an increased willingness to actually be involved in EU policy or scrutiny of the government (Auel, 2015). In this respect, Wessels (2005) analysed contact patterns of German MPs, their involvement in EU policy-making and their perceptions of the control of power over time (1997-2003), and concluded that 'attitudinal parliamentarization' certainly takes place, but only at a very slow pace.

To evaluate actual parliamentary behaviour, secondly, it makes sense to turn to the traditional parliamentary functions, to see how these have evolved in an EU context: electing governments, drafting legislation, scrutinizing the government, and communicating to the wider citizenry (Auel, Rozenberg, \& Tacea, 2015). It is widely acknowledged that the first two of these functions do not readily apply to national parliaments, because in an EU context the European Parliament has largely taken these over. Hence, the focus is on scrutiny of the government, and more recently on the communicative function, to assess if and how 'behavioural parliamentarization' takes place.

When it comes to parliamentary control and oversight, the main conclusion is one of differentiation across time and countries (Raunio, 2009; Winzen, 2012). Auel et al. (2015) tested six institutional and motivational hypotheses on a unique dataset of 27 parliaments, and found that it was mainly the institutional strength in EU affairs and (more limitedly) the type of parliamentary system (majority or consensus) that explained the divergence in the time spent in EACs, and in drafting resolutions. However, Senninger (2017) also convincingly shows that partisan competition has a defining influence on parliamentary EU oversight, as EU issuebased incentives across parties have been shown to explain the content and timing of oversight activities. National parliaments have over the years also established horizontal links with other parliaments, resulting in inter-parliamentary fora in order to be better able to follow European policies and share best practices (Raunio, 2009).

Furthermore, building on normative and democratic concerns, it is particularly the communicative function that has moved centre stage over the past five years (Auel \& Raunio, 2014b). Democracy depends on a lively and viable public debate, where policy alternatives are presented to citizens to make informed choices. In this respect, national parliaments are argued to be in a unique position to translate EU policies, 'bring the EU home' and normalize its existence (Auel, 2007; Kröger \& Bellamy, 2016). As such, communication by national parliaments (and its members) can add to the democratic legitimacy of the EU polity as a whole. The extent to which they do this, "and are seen by citizens to carry out such actions" is hence arguably fundamental for the legitimacy of the political system (Auel \& Raunio, 2014b, p. 3).

However, while it might be theoretically true that "national parliaments provide a major space for public debate and are thus ideal arenas for the deliberation of important European issues" (Auel, 2007, p. 498), there is not a great deal of empirical knowledge about whether they actually do so. National parliaments can play this role in different ways (Auel \& Raunio, 2014b): informing the electorate, asking parliamentary questions, or making transcriptions of debates publicly available. A major role is however envisioned for plenary debates. The plenary is an ideal forum to articulate specific positions on a variety of (European) issues, commonly placing them next to other parties and politicians. The literature does, however, acknowledge that a translation of these debates to the mass media is often required to be able to make these debates actually visible to the public (Auel, Eisele, \& Kinski, 2018).

Despite its theoretical importance, early results led to fairly depressing conclusions. In a special issue specifically focused on the communicative function of national parliaments, Auel and Raunio (2014b) summarized that, generally speaking, national parliaments "seem not to live up to their task of bringing 'Europe' closer to the citizens or enabling them to make informed political choices and to exercise democratic control in EU affairs" (p. 10). Especially in plenary debates, the EU remains "a rare guest" (Auel \& Raunio, p. 7). While some institutional determinants seem important (such as the formal rights granted to parliament, or the existence of a 'talking' instead of a 'working' parliament, see De Wilde, 2011b), it appears that incentive structures play a more decisive role in accounting for plenary debates and communication in general (Auel \& Raunio, 2014a; Auel et al., 2015).

In this respect, it is often the 'public salience' criterion that reappears in analyses of the communicative function, disguised in different topics (Auel, 2015). The topic of the euro crisis, for example, was shown to be a better predictor of parliamentary debates than some institutional factors, simply because the public salience surrounding it was so high (Auel et al., 2015; Auel \& Höing, 2014; Wendler, 2013). Miklin (2014) equally shows that in Germany and Austria, national parliaments discussed the EU Services Directive heavily, but only after the public salience of the issue had grown. In EU foreign policy as well, recent studies have found national parliaments in different Member States heavily debated EU free trade negotiations (with Canada and the US), but only after the public salience of these issues had grown significantly (Bollen, 2018; Gheyle, 2019).

All in all, the current literature documents that a process of institutional parliamentarization of the EU has definitely taken place while raising several questions regarding the existence of a pattern of attitudinal and behavioural parliamentarization. The former appears to be 
moving slowly, while the latter varies widely between countries, and according to specific (salient) episodes in time-especially when it comes to parliamentary communication and debates. In other words: The ability to deal with EU issues is, generally speaking, present, but incentive structures seem to inhibit their use. Following Raunio (2009), national parliaments may hence not be 'late comers' to the EU debate, but simply rationally not engaging having weighed up the pros and cons.

\section{Politicization of EU Integration and Policies}

In the past 20 years, the so-called 'permissive consensus' towards European integration has abruptly come to an end (Hooghe \& Marks, 2009). Different manifestationslisted in the introduction-are testimony of the fact that both support for and contestation against the EU have gradually become integral components of contemporary societal and political life (Zürn, Binder, \& Ecker-Ehrhardt, 2012). This arguably has profound consequences for European integration and its democratic functioning. On the one hand, scholars argue that the fact that publics are now "looking over the shoulders" of EU elites, and that the EU has become an element of mass politics, constitutes a 'constraining dissensus' for further integration (Hooghe \& Marks, 2009). On the other hand, (public sphere) scholars see a large democratizing potential in frequently debating (and conflicting over) the EU, and in doing so providing citizens with alternatives, contestation, and options to fight for-the core elements of a vibrant democracy (Follesdal \& Hix, 2006; Statham \& Trenz, 2015). Whatever the stance, the politicization of European integration, in any case, seems to be understood as having a profound impact on further European (dis)integration, which makes it a key research topic for years to come.

From an academic point of view, the first tasks are therefore to conceptualize the politicization phenomenon and its relation to 'politics', as well as to analytically capture its varying manifestations, in order to measure its occurrence and extent. From a conceptual point of view, politicization implies a special case of 'turning something political', combining the visible and contested aspects of 'the political' (Palonen et al., 2019). The underlying idea is hence that the existence of the EU, or its policies and decisions, are debated and no longer escape the wider public's attention (Rauh, 2016). This means that the commonly executive, elite-driven process of European integration is no longer taken for granted, and frequently falls prey to heated and mass public debate (Rauh, 2016). Analytically, the starting point is often the contribution by De Wilde (2011a), who defined politicization as "an increase in polarization of opinions, interests or values and the extent to which they are publicly advanced towards the process of policy formulation within the EU" (p. 566).

Given the broad scope of this operational definition, there is an on-going debate on how to measure and make sense of politicization, specifically in terms of the types of 'manifestations' and 'settings' it comprises; the ways in which the phenomenon becomes visible for researchers to study its existence and extent (see Gheyle, 2019, for an exhaustive discussion). Various contributions have initially led to a convergence around the idea that three sub-processes constitute politicization: salience, actor (or audience) expansion, and polarization (De Wilde et al., 2016). Nevertheless, the different interpretations that can be generated by these terms, have led to two overarching approaches to analysing politicization: as a purely (or predominantly) discursive phenomenon, or as a much more encompassing phenomenon.

In the first, widely-held approach, politicization is seen as an essentially discursive phenomenon that builds on political communication. As Hurrelmann, Gora and Wagner (2015) put it, in this approach, it is "not sufficient that actors become aware, or able to form opinions, but it must become salient in political communication that seeks to influence decision-making" (p. 45). Applying the sub-processes here means seeing politicization as a visible, discursive, expansion of the scope of conflict, whereby different types of groups or political actors publicly conflict over a certain topic, fuelled by different opinions, ways of framing, or legitimations of the EU or its policies (Gheyle, 2019; Statham \& Trenz, 2015). As such, the focus is on the "communicative processes that lead to an increasing intensity and controversy of debates" and on the settings or arenas where this can visibly play out (Schmidtke, 2014, p. 3).

To speak of politicization in this view entails two things: (i) there are actors present who deliberately raise issues; and (ii) that these issues are raised in public, in front of an audience. Politicization, therefore, does not happen automatically but builds on societal or political actors seeking publicity and resonance with a wider audience who are able to witness these actions (De Wilde, 2011a; Statham \& Trenz, 2015). Where these discursive interventions can take place-and hence where we could eventually see evidence of politicization-are in those settings or arenas where there actually is a larger audience able to follow an unfolding debate. Parliaments, the mass media, 'on the streets', town hall assemblies, or scientific conferences all fit that description (De Wilde, 2011a). Several authors have therefore come up with a classification of three types of settings in which to find and study politicization: institutional, intermediary, and citizen settings (Baglioni \& Hurrelmann, 2016; De Wilde et al., 2016).

The institutional setting mainly comprises parliamentary arenas, where professional politicians engage in political debate about different (European) issues. The length of parliamentary debates or the polarization between different parties about core EU policies is therefore sometimes used as indicators of a politicized object (Green-Pedersen, 2012; Wendler, 2013; Wonka, 2016). The second intermediary setting serves as the link between political decision-making and the broader citizenry and civil society. While there is some research on 
party manifestos (Guinaudeau \& Persico, 2013) and public protest (Hutter, Grande, \& Kriesi, 2016), the main focus is on the public sphere carried by the (mass) media (De Wilde et al., 2016; Hoeglinger, 2016). With its wide audience reach, and its central place in contemporary 'audience democracies' (Manin, 1997) the mass media arguably serves as the primus inter pares location to study politicization (Gheyle, 2019). Finally, the citizen setting has been least studied (but see Baglioni \& Hurrelmann, 2016). It comprises arenas made up of laypeople engaging with politics, coming together, for example, in debating groups or on social media.

The main focus in politicization research in all of these settings is on domestic arenas: national parliaments; domestic public (media) spheres; or domestic protest. This is because structural barriers, such as language differences or the nationally structured media systems, still inhibit pan-European debates or conflict expansion. For this reason, a multitude of institutional and agency-related variables are said to result in a "differentiated politicization of European governance, in which patterns vary substantially across settings and time" (De Wilde et al., 2016, p. 9). This pattern has been confirmed in several empirical studies (see Zürn, 2018, for an overview), and has fuelled the theoretical debate about which structural and agency related variables may explain the divergence (Gheyle, 2019; Zürn, 2016).

Besides the discursive-centred approach, a second approach claims that politicization analytically implies much more than just public debate or political communication (Hooghe \& Marks, 2009; Rauh, 2016; Zürn et al., 2012). Driven by a different account of what the political' implies, it is argued that several other manifestations can also point to the fact that something is politicized (Zürn, 2016). Changing attitudes and beliefs about the EU (or core policies), various group activities, such as lobbying, coalition formation, voting trends, or the (in camera) parliamentary scrutiny of European issues are in this sense also testimony of its politicization. While these accounts acknowledge that communication is important, and that politicization can play out in different settings, they argue we need to take these other types of manifestation into account. Especially when we take a longerterm view of the politicization of the EU. In Table 1, three recurring manifestations are summarized, with examples of what could be seen as evidence of politicization.
The key insight here is that the three manifestations of politicization in the institutional setting largely overlap with the attitudinal and behavioural parliamentarization of the EU as introduced in the previous section. The parliamentary communication function logically overlaps with political communication in the institutional setting. Increased parliamentary scrutiny of EU affairs is less visible to the wider public but is still a political activity that implies a heightened importance of the EU or a certain policy. Even the increasing awareness of MPs about their role in multi-level policy-making, or about the importance of a certain EU policy, can be seen as evidence of politicization (in the broader approach). In sum, different types of parliamentarization of the EU can be conceptualized as (as I will argue: necessary, yet insufficient) components of a broader politicization dynamic.

This means that the choice for the narrow or broad approach towards politicization is important to assess the relationship between parliamentarization and politicization. In the broad approach, attitudinal parliamentarization and the scrutiny aspect of behavioural parliamentarization might be labelled particular manifestations of the politicization of the EU. While this obviously has its merits to analyse longer-term dynamics in the EU multi-level polity, it can also lead to contradictory tendencies. Christiansen, Högenauer and Neuhold (2014), for example, theorized that institutional parliamentarization, and the related scrutiny practices, may also result in increased bureaucratization and depoliticization, as tighter scrutiny practices may favour expert bureaucrats, to the detriment of more visible and polarized political discussions in plenary.

For this and other reasons (see Gheyle, 2019, Chapter 2), I argue it is most helpful to think of politicization in the narrow view set out above, as a primarily discursive phenomenon that builds on the other manifestations functioning as latent potentialities. This narrow approach is also more suited to deal with short-term politicization phenomena, as is the case when focusing on European policies. Doing so also clarifies the relationship between (the communicative aspect of) behavioural parliamentarization and politicization. It is visible, polarized, parliamentary communication (most likely seen in plenary debates) that is considered the (necessary, yet insufficient) component of the broader (discursive) politicization of an EU issue. In the next section, I argue that

Table 1. Examples of manifestations of politicization across different settings.

\begin{tabular}{llll}
\hline & Institutional setting & Intermediary setting & Citizen setting \\
\hline Beliefs/attitudes & MP views on EU integration & Expert views & Public opinion \\
\hline Political activities & $\begin{array}{l}\text { Scrutiny or follow-up } \\
\text { of EU issues }\end{array}$ & $\begin{array}{l}\text { Associational activity, protest, } \\
\text { lobbying, coalition formation }\end{array}$ & $\begin{array}{l}\text { Public protest, electoral } \\
\text { turnout, voting behaviour }\end{array}$ \\
\hline Political communication & $\begin{array}{l}\text { Parliamentary debates } \\
\text { in plenary }\end{array}$ & $\begin{array}{l}\text { Mass media, party manifestos, } \\
\text { press releases }\end{array}$ & Layperson's discourse \\
\hline
\end{tabular}

Notes: Own elaboration, inspired by Zürn (2016) and Hurrelmann et al. (2015). 'Narrow' approach to politicization comprises the third row, while the broad approach comprises all three. 
we not only can but also should be seeing these phenomena as intertwined.

\section{The Importance of an Integrated View}

In the previous part, I argued that it is analytically possible to see (the communicative aspect of) behavioural parliamentarization as a component of a wider politicization phenomenon. In this penultimate section, I add that we also should be seeing the former as a necessary, yet insufficient, component of politicization, for three reasons: (i) it goes beyond often ad hoc or pars pro toto theoretical assumptions in both literatures; (ii) it sheds new light on the normative consequences usually attached to both; and (iii) it furthers a more complete understanding of how 'comprehensive' politicization of European policies unfolds.

\subsection{From 'Partial' to 'Comprehensive' Phenomena}

A first reason to study these phenomena together is that we no longer have to resort to ad hoc or pars pro toto theoretical assumptions related to the original concepts. The literature on parliamentary communication, for example, often has to include publicly salient topics, or the introduction of broad variables such as 'Euroskepticism' in order to explain the existence and extent of communication (e.g., Auel et al., 2015). Arguably, it cannot be the aim to identify-a priori-all possible salient issues in order to explain this parliamentary function, nor is 'Euroskepticism' a readily interpretable indication of why some issues pop up in parliamentary debates while others do not. Explaining parliamentary communication makes more sense from the point of view of the issue, rather than the institution or characteristics of the country (even though these can play mediating roles). This could be attained by linking with the wider concept of 'politicization' of European policy.

Furthermore, national parliaments are not simply passive receivers of societal pressures that they must then translate into political action. They are an integral cog in a wider politicization dynamic, often able to decide whether to add visibility to certain EU issues, or whether to silence them. In his study of the EU Services Directive, Miklin (2014) for example, found that left parties aimed to "increase public pressure further and hence prevent the directive from being adopted" (p. 86). De Wilde (2014) states that "national parliaments can contribute to the politicization of Europe by exercising their communicative role, but the main communicative arena that reaches citizens is constituted by mass media, rather than parliaments" (p. 46). It, therefore, seems almost inevitable that the function of parliamentary communication is studied in parallel with the study of mass media (Auel et al., 2018).

In the politicization literature, secondly, it is often the case that evidence of one manifestation is taken to mean full-blown politicization. Some authors equate politicization with political parties picking up an issue, irrespective of whether the issue is visible to a wider public or not (e.g., Green-Pedersen, 2012; Hooghe \& Marks, 2009). Herranz-Surrallés (2018) identifies an increasing polarization between political parties (in the European Parliament) and labels this as politicization. Miklin (2014) argues that we need to assess how 'EU politicization' can increase in order to affect the way national parliaments deal with these issues, implying that the former is something independent from parliamentary involvement. Zürn et al. (2012) label the increasing involvement of NGOs at the international level as politicization. Lastly, many contributions focus on the mass media setting as the most important location to study politicization but in doing so run the risk of narrowing the phenomenon to media visibility (see Zürn, 2016).

Recall that politicization is a complex, multi-faceted phenomenon, that aims to tie together different (types of) manifestations in different settings. There is therefore arguably a risk in labelling something 'politicization' if it only manifests itself in one way or one particular setting. Just as a complex concept such as 'democracy' is not reducible to one constitutive element (such as free elections), so politicization is not present as soon as there is 'protest' or 'media visibility'. It, therefore, makes sense to claim that political or societal debate in only one setting should be labelled a 'partial' form of politicization and if there is a spillover between different settings (parliaments and mass media) as 'comprehensive' politicization. Doing so would also (partly) address the thorny question of the 'extent' of politicization (What is high or low? Is there a threshold?), by arguing that we should at least be seeing parliamentary and mediated communication.

\subsection{Normative Consequences}

Besides theoretical and analytical reasons, there are also normative considerations that justify a closer connection between behavioural parliamentarization and politicization. Recall that both politicization and parliamentarization imply a normative, democratic component: Widespread public debate, and the particular translation hereof in parliament, is argued to be a constitutive force of democratization. Here too, however, it seems incorrect to assume that these far-reaching beneficial outcomes result from their partial manifestations only.

For national parliamentary debates this is acknowledged, and intuitively clear: If parliamentary debates do not spill over beyond the assembly walls, it is quite difficult to attach far-reaching normative consequences to the fact that they have taken place. Who saw them, what informing, aggregating, or polarizing function did they have? As Auel et al. (2018) succinctly put it: "Despite a remarkable increase in parliamentary involvement in EU affairs, the added value in terms of democratic legitimacy will remain limited if citizens are not aware of their activities". While social media may have a role to play 
here (even though there is doubt regarding the extent to which it can provide a balanced picture), the mass media remains the primary transmission channel for carrying these debates to the wider public.

The same reasoning applies for those contributions that study politicization as manifested in the primus inter pares setting, the mass media. While undoubtedly important, the point is that the existence of polarized and mediated debates about EU issues may not be sufficient to attribute large normative consequences if, for example, these do not imply any domestic conflict (De Wilde \& Lord, 2016). What deliberative, normative, consequences should we attach to those debates about and between foreign or European actors, making EU issues seem as remote, or as if played out between others, and not us?

Arguably, what matters from a normative point of view is a connection between the (deliberative) opinion-making process and the decision-making level (Papadopoulos, 2013, p. 77). MPs, and the parliament itself, play a major role in (selectively) increasing the resonance of this public debate, increasing (potential) responsiveness by executive actors. If the existing power structures (such as governments or the European Commission) are disconnected from (or relatedly: irresponsive to) wider public debates, we should not hold public debates in such high (normative) regard simply because they happen. This could just as well constitute a 'dialogue of the deaf' (Crespy, 2014), which in the end fuels the (perceived) lack of legitimacy of the EU (Crespy, 2016). In sum, to genuinely speak of a politicized issue, outside debates need an inside translation, or they could evaporate in the already crowded public sphere.

This point is backed up most explicitly by Kröger and Bellamy (2016), who argue that what is lacking, is not (primarily) democracy at the EU level, but a democratic (re)connection between EU decision-making and the nationally-bound citizenry. In the current set-up, national parliaments are crucial in order to domesticate and normalize the EU. Domestication, they argue, is already well underway, since in their view this overlaps with institutional parliamentarization (cf. Kröger \& Bellamy, 2016). Normalization, however, means debating "alternative EU policies by non-Euroskeptic parties according to their characteristic ideological commitments" (Kröger \& Bellamy, 2016, p 14). Hence, the (beneficial) normative consequences scholars attach to politicization may only materialize depending on far-reaching domestication and normalization of the EU. This arguably has a better chance when the objects are specific EU policies, where citizens can readily observe the wider societal debates and how political parties deal with those in their domestic parliaments.

\subsection{Explanatory Potential}

Finally, we should be linking both phenomena together because it helps us advance a more complete understanding of how this 'comprehensive' politicization de- velops. This firstly means looking for the conditions under which a spillover from wider societal debates to parliamentary settings (or the other way around) occurs. Several of such 'spillover' variables have already been identified, but have not been placed into an overarching framework due to the separate evolvement of these strands of literature. When it comes to the conditions generally considered necessary for political parties to pick up and openly communicate about EU issues, four variables are raised: (i) the issue must be salient; (ii) the party position must be in line with their voters; (iii) the party needs to be internally cohesive on the topic; and (iv) the competitors should take up alternative positions (Kröger \& Bellamy, 2016; Miklin, 2014).

Interestingly, the spillover from parliamentary to wider societal settings (e.g., mass media) seems to be based on similar considerations. Auel et al. (2018) studied different supply and (media) demand hypotheses about when parliamentary activity is covered in newspapers, and have found that there is a large role for parliamentary news supply. In other words: The media is certainly interested in parliamentary debates about EU issues, but there have to be such events in the first place.

Political parties or specific MPs are therefore key players. However, Kiiver (2007) argues that there is a range of trade-offs involved for MPs that impact their decisions to highlight EU issues, to take up contrasting positions, and to attempt to generate an impact on EU policy outcomes. Hence, further research should investigate not only if plenary debates, or political communication by MPs, about European issues takes place, but also what the underlying motivation is to do so, and when they abstain from it (see Senninger, 2017). This can be related to party variables, such as their ideology, or their place in government-opposition, but also to role division perceptions with the European Parliament, or issue-specific variables, such as distinctions between distributive, regulatory or foreign policy issues, or the way parties are able to link (frame) EU policies to their domestic agenda.

Besides highlighting issues themselves, parties may, of course, react to publicly salient topics, which means we also need to take into account how societal debate expands from initial discursive interventions, to its entrance in (semi-)public arenas and ultimately in parliaments (Palonen et al., 2019). Recent studies on the derailing of the Anti-Counterfeiting Trade Agreement (Crespy \& Parks, 2017; Dür \& Mateo, 2014) and the Transatlantic Trade and Investment Partnership (TTIP; Gheyle, 2019) have shown how interest groups and social movements succeeded in making complex foreign policy issues publicly salient, after which both national and European MPs picked it up. They point to normative framing strategies, pan-European coalition formation between groups, close ties with parliamentary actors, and outside lobbying efforts in terms of demonstrations and social media campaigns.

While the previous points all suggest agency-related variables, we also need to take into account the struc- 
tural variables which inhibit or facilitate conflict expansion. In terms of parliamentary communication, for example, the either ex-ante or ex-post dealing with EU policy issues matters significantly (De Wilde, 2011b). When the issue is initially left to executives and the administration, heated debates often follow at the end of the policy cycle. When close (ex-ante) scrutiny has been paid throughout, less conflict appears to emerge afterwards. Gheyle (2019), furthermore, shows that Irish advocacy groups faced enormous difficulties in getting media attention for their TTIP cause, in part because of a hostile media environment (in contrast with the very open and pluralist German media system). Hence, the introduction of political and/or discursive opportunity structures should help explain the expansion or contraction of conflicts within and across settings.

A modest research agenda should therefore primarily aim to disentangle (through theory-testing processtracing or qualitative comparative analysis) which combination of variables (or which mechanisms) explain 'comprehensive' politicization. Such a case-based research design is all the more important given that these 'comprehensive' phenomena might take place much less frequently than we think. Kiiver (2007) even argues that we can at best expect 'targeted' politicization: some specific EU policies, which attract deliberate attention by national parliaments, while the bulk of policies pass unnoticed. This is in line with the idea that politicization is essentially about how public and political attentiona scarce resource-flows (Palonen et al., 2019). A certain politicized issue might detract attention, resources, and debate from another, pre-empting a comparative analysis of different issues. A qualitative research agenda unpacking the dynamics of successful 'comprehensive' politicized issues is, therefore, better suited than large $\mathrm{N}$ projects.

\section{Conclusions}

In this contribution, I have looked at the phenomena of (behavioural) parliamentarization and politicization from a conceptual and analytical angle in order to set the scene for the empirical contributions in this special issue. The key point I put forward is simple, but arguably often overlooked: We can and should be seeing (behavioural) parliamentarization as a necessary, yet insufficient, component of a wider politicization phenomenon, and not as separate processes that react to each other. By concisely reviewing both literature strands and deconstructing these concepts, I have first of all shown that this is perfectly possible, analytically speaking.

With a further focus on the communicative aspects of behavioural parliamentarization and politicization, I have argued that we also should be seeing these as tightly interwoven, as it: (i) goes beyond ad hoc or pars pro toto theoretical assumptions in each separate literature strand; (ii) sheds new light on the normative consequences scholars usually attach to both; and (iii) helps ad- vance a more complete understanding and explanation of these phenomena.

There are of course several limitations to this contribution. First of all, I have only focused on the role and activities of national parliaments, while their functioning and behaviour is also dependent on the place they have been granted (or carve out for themselves) in a multi-level parliamentary system. The relationship between these different levels is complex, even without questioning what multi-level politicization would look like (see Crum \& Fossum, 2009). This contribution hopefully serves as a conceptual and analytical stepping stone for further research dealing with these complexities.

Secondly, as Table 1 shows, the citizen setting is also identified as a location for politicization to unfold, yet this is under-researched. An important consideration is if we should take this setting into account as well to make sure that any 'comprehensive politicization' we might witness, does not take place before a 'blind audience'. While it makes sense to assume that issues that are contested simultaneously in parliament and in the mass media are also on the public's attention radar, we cannot rule out the possibility that citizens' changing media intake (e.g., through social media) fractures these links, and hence impacts the normative consequences attached to comprehensive politicization.

Thirdly, the current contribution identifies overlap predominantly in terms of the location and manifestations of politicization and parliamentarization but says little about the content of the debates that are being held. Any beneficial normative consequences attached to these phenomena obviously also depend on the way the EU is debated, and if position-taking and framing follow traditional political cleavages or if new ones are established (see e.g., Wendler, 2013). While it is here implied that contestation or 'polarization' is present as a necessary sub-process of politicization (and can arguably be seen as an empirical likelihood), empirical research should verify this in parallel, instead of only looking at where discursive interventions take place.

\section{Acknowledgments}

The author wishes to thank the three anonymous reviewers and the editorial team for their valuable feedback on the first version of this article.

\section{Conflict of Interests}

The author declares no conflict of interests.

\section{References}

Auel, K. (2007). Democratic accountability and national parliaments: Redefining the impact of parliamentary scrutiny in EU affairs. European Law Journal, 13(4), 487-504.

Auel, K. (2015). Europeanization of national parliaments. 
In J. Magone (Ed.), Handbook of comparative European politics (pp. 366-385). London: Routledge.

Auel, K., Eisele, O., \& Kinski, L. (2018). What happens in parliament stays in parliament? Newspaper coverage of national parliaments in EU affairs. JCMS: Journal of Common Market Studies, 56(3), 628-645.

Auel, K., \& Höing, O. (2014). Parliaments in the euro crisis: Can the losers of integration still fight back? Journal of Common Market Studies, 52(6), 1184-1193.

Auel, K., \& Raunio, T. (2014a). Debating the state of the union? Comparing parliamentary debates on EU issues in Finland, France, Germany and the United Kingdom. The Journal of Legislative Studies, 20(1), 13-28.

Auel, K., \& Raunio, T. (2014b). Introduction: Connecting with the electorate? Parliamentary communication in EU affairs. The Journal of Legislative Studies, 20(1), 1-12.

Auel, K., Rozenberg, O., \& Tacea, A. (2015). To scrutinise or not to scrutinise? Explaining variation in EUrelated activities in national parliaments. West European Politics, 38(2), 282-304.

Baglioni, S., \& Hurrelmann, A. (2016). The Eurozone crisis and citizen engagement in EU affairs. West European Politics, 39(1), 104-124.

Bollen, Y. (2018). The domestic politics of EU trade policy: The political economy of CETA and anti-dumping in Belgium and the Netherlands (Unpublished Doctoral dissertation). Ghent University, Ghent, Belgium.

Christiansen, T., Högenauer, A. L., \& Neuhold, C. (2014). National parliaments in the post-Lisbon European Union: Bureaucratization rather than democratization? Comparative European Politics, 12(2), 121-140.

Crespy, A. (2014). A dialogue of the deaf? Conflicting discourses over the $\mathrm{EU}$ and services liberalisation in the WTO. The British Journal of Politics and International Relations, 16(1), 168-187.

Crespy, A. (2016). Welfare markets in Europe: The democratic challenge of European integration. Basingstoke and New York, NY: Palgrave Macmillan.

Crespy, A., \& Parks, L. (2017). The connection between parliamentary and extra-parliamentary opposition in the EU. From ACTA to the financial crisis. Journal of European Integration, 39(4), 453-467.

Crum, B., \& Fossum, J. E. (2009). The multilevel parliamentary field: A framework for theorizing representative democracy in the EU. European Political Science Review, 1(2), 249-271.

De Wilde, P. (2011a). No polity for old politics? A framework for analyzing the politicization of European integration. Journal of European Integration, 33(5), 559-575.

De Wilde, P. (2011b). Ex ante vs. ex post: The trade-off between partisan conflict and visibility in debating EU policy-formulation in national parliaments. Journal of European Public Policy, 18(5), 672-689.

De Wilde, P. (2014). The operating logics of national parliaments and mass media in the politicisation of Eu- rope. The Journal of Legislative Studies, 20(1), 46-61.

De Wilde, P., Leupold, A., \& Schmidtke, H. (2016). Introduction: The differentiated politicisation of European governance. West European Politics, 39(1), 3-22.

De Wilde, P., \& Lord, C. (2016). Assessing actuallyexisting trajectories of EU politicisation. West European Politics, 39(1), 145-163.

Dür, A., \& Mateo, G. (2014). Public opinion and interest group influence: How citizen groups derailed the Anti-Counterfeiting Trade Agreement. Journal of European Public Policy, 21(8), 1199-1217.

Follesdal, A., \& Hix, S. (2006). Why there is a democratic deficit in the EU: A response to Majone and Moravcsik. Journal of Common Market Studies, 44(3), 533-562.

Gheyle, N. (2019). Trade policy with the lights on. The origins, dynamics, and consequences of the politicization of TTIP (Unpublished Doctoral dissertation). Ghent University, Ghent, Belgium.

Goetz, K., \& Meyer-Sahling, J.-H. (2008). The Europeanization of national political systems: Parliaments and executives. Living Reviews in European Governance, 3(2), 1-30.

Green-Pedersen, C. (2012). A giant fast asleep? Party incentives and the politicisation of European integration. Political Studies, 60(1), 115-130.

Guinaudeau, I., \& Persico, S. (2013). EU politicization through the lens of salience: How the EU enters the French, British and German electoral agenda (1986-2009). French Politics, 11(2), 143-168.

Herranz-Surrallés, A. (2018). Paradoxes of parliamentarization in European security and defence: When politicization and integration undercut parliamentary capital. Journal of European Integration, 41(1), $1-17$.

Hoeglinger, D. (2016). Politicizing European integration: Struggling with the awakening giant. Basingstoke and New York, NY: Palgrave Macmillan.

Hooghe, L., \& Marks, G. (2009). A postfunctionalist theory of European integration: From permissive consensus to constraining dissensus. British Journal of Political Science, 39(1), 1-23.

Hurrelmann, A., Gora, A., \& Wagner, A. (2015). The politicization of European integration: More than an elite affair? Political Studies, 63(1), 43-59.

Hutter, S., Grande, E., \& Kriesi, H. (2016). Politicising Europe. Cambridge: Cambridge University Press.

Kiiver, P. (2007). Europe in parliament: Towards targeted politicization. Scientific Council for Government Policy, 2007(23), 1-44.

Kröger, S., \& Bellamy, R. (2016). Beyond a constraining dissensus: The role of national parliaments in domesticating and normalising the politicization of European integration. Comparative European Politics, 14(2), 131-153.

Ladrech, R. (1994). Europeanization of domestic politics and institutions: The case of France. Journal of Common Market Studies, 32(1), 69-88. 
Manin, B. (1997). The principles of representative government. Cambridge: Cambridge University Press.

Maurer, A., \& Wessels, W. (2001). National parliaments on their ways to Europe. Losers or latecomers? BadenBaden: Nomos Verlag.

Miklin, E. (2014). EU politicisation and national parliaments: Visibility of choices and better aligned ministers? The Journal of Legislative Studies, 20(1), 78-92.

Neuhold, C., \& Smith, J. (2016). Conclusion: From 'latecomers' to 'policy shapers'?-The role of NPs in the Post-Lisbon Union. In C. Hefftler, C. Neuhold, O. Rozenberg, \& J. Smith (Eds.), The Palgrave handbook of national parliaments and the European Union (pp. 668-686). Basingstoke and New York, NY: Palgrave Macmillan.

Palonen, K., Wiesner, C., Selk, V., Kauppi, N., Trenz, H.J., Dupuy, C., \& Van Ingelgom, V. (2019). Rethinking politicization. Contemporary Political Theory, 18(2), 248-281.

Papadopoulos, Y. (2013). Democracy in crisis? Politics, governance and policy. London: Macmillan International Higher Education.

Rauh, C. (2016). A responsive technocracy? EU politicisation and the consumer policies of the European Commission. Colchester: ECPR Press.

Raunio, T. (2009). National parliaments and European integration: What we know and agenda for future research. The Journal of Legislative Studies, 15(4), 317-334.

Raunio, T., \& Hix, S. (2000). Backbenchers learn to fight back: European integration and parliamentary government. West European Politics, 23(4), 142-168.

Roederer-Rynning, C., \& Schimmelfennig, F. (2012). Bringing codecision to agriculture: A hard case of parliamentarization. Journal of European Public Policy, 19(7), 951-968.

Rozenberg, O., \& Hefftler, C. (2016). Introduction. In C. Hefftler, C. Neuhold, O. Rozenberg, \& J. Smith (Eds.), The Palgrave handbook of national parliaments and the European Union (pp. 1-39). Basingstoke and New York, NY: Palgrave Macmillan.

Schmidtke, H. (2014). Explaining the politicization of international institutions. Paper presented at the 23rd World Congress of Political Science, Montréal, Canada.

Senninger, R. (2017). Political parties and parliamentary EU oversight (Unpublished Doctoral dissertation). Aarhus University, Aarhus, Denmark.

Statham, P., \& Trenz, H.-J. (2015). Understanding the mechanisms of EU politicization: Lessons from the Eurozone crisis. Comparative European Politics, 13(3), 287-306.

Van der Eijk, C., \& Franklin, M. (2004). Potential for contestation on European matters at national elections in Europe. In G. Marks \& M. Steenbergen (Eds.), European integration and political conflict (pp. 32-50). Cambridge: Cambridge University Press.

Wendler, F. (2013). Challenging domestic politics? European debates of national parliaments in France, Germany and the UK. Journal of European Integration, 35(7), 801-817.

Wessels, B. (2005). Roles and orientations of members of parliament in the EU context: Congruence or difference? Europeanisation or not? The Journal of Legislative Studies, 11(3/4), 446-465.

Wessels, W., Maurer, A., \& Mittag, J. (2003). Fifteen into one? The European Union and its member states. Manchester: Manchester University Press.

Winzen, T. (2012). National parliamentary control of European Union affairs: A cross-national and longitudinal comparison. West European Politics, 35(3), 657-672.

Wonka, A. (2016). The party politics of the Euro crisis in the German Bundestag: Frames, positions and salience. West European Politics, 39(1), 125-144.

Zürn, M. (2016). Opening up Europe: Next steps in politicisation research. West European Politics, 39(1), 164-182.

Zürn, M. (2018). A theory of global governance: Authority, legitimacy, and contestation. Oxford: Oxford University Press.

Zürn, M., Binder, M., \& Ecker-Ehrhardt, M. (2012). International authority and its politicization. International Theory, 4(1), 69-106.

\section{About the Author}

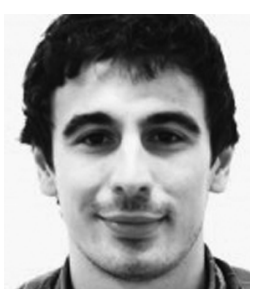

Niels Gheyle is a Postdoctoral Researcher at the Centre for EU Studies (CEUS), Ghent University. His research interests revolve around the (de)politicization of EU trade policy, European integration, and global governance. He finished his doctoral dissertation in 2019, focusing on the origins, dynamics, and consequences of the politicization of TTIP. 